\title{
Fine-scale layer of hydromedusae is revealed by video plankton recorder (VPR) in a semi-enclosed bay in northern Norway
}

\author{
H. P. Jacobsen*, M. F. Norrbin \\ Norwegian College of Fishery Sciences, University of Tromsø, 9037 Tromsø, Norway
}

\begin{abstract}
High resolution images of zooplankton organisms were recorded in situ using a digital autonomous video plankton recorder (VPR) in a semi-enclosed bay in northern Norway. Data from vertical VPR profiles was used to estimate the depth distribution and abundance of zooplankton along a bay-wide grid. Images were recorded simultaneously with hydrographical data, and the spatial distribution of different organisms was related to several water column characteristics, such as chlorophyll $a$, density, and buoyancy frequencies. In June, unusually high abundances of hydromedusae (Rathkea octopunctata and Obelia sp.) were located in a fine-scale layer of a few metres thickness. This layer could be associated with relatively high buoyancy frequencies, reflecting a density gradient present throughout the entire sampling area. Aggregation of hydromedusae around density discontinuities may have enabled retention of medusae in the bay. Ctenophores and appendicularians were distributed above the medusae layer, while peaks of copepod abundance were found outside the layer boundaries. We suggest that the bloom of $R$. octopunctata was initially caused by liberation of new medusae from successful benthic hydroid colonies, and that proliferation of this species was sustained by asexual, manubrial budding in the medusae stage.
\end{abstract}

KEY WORDS: Zooplankton $\cdot$ Hydromedusae $\cdot$ Video plankton recorder $\cdot$ Vertical distribution Resale or republication not permitted without written consent of the publisher

\section{INTRODUCTION}

Plankton patchiness is a well-documented phenomenon and is of great importance for biological productivity, nutrient cycling, and food web dynamics in planktonic ecosystems (Mackas et al. 1985, Pinel-Alloul 1995). The use of advanced optical and acoustic sensors have made it possible to identify micro-scale $(<1 \mathrm{~m})$ and fine-scale $(1$ to $10 \mathrm{~m})$ vertical plankton patches (Davis et al. 1992, Holliday et al. 1998, Cowles et al. 1998) that may extend horizontally for several km (Bjørnsen \& Nielsen 1991). These plankton features, sometimes referred to as thin layers, occur as coherent and well-defined layers in the water column with distinct biological, chemical, optical, and physical properties (Cowles et al. 1998, Hanson \& Donaghay 1998). Thin layers may consist of high concentrations of phytoplankton, zooplankton, bacteria, virus, or marine snow (Johnson et al. 1995, Alldredge et al. 2002, McManus et al. 2003), and have been detected in various marine habitats, such as estuaries (Donaghay et al. 1992), fjords (McManus et al. 2003), river mouths (Gentien et al. 1995), and open oceans (Bjørnsen \& Nielsen 1991).

Plankton patches are driven by physical and biological processes (Mackas et al. 1985, Folt \& Burns 1999), and it has been suggested that physical forces dominate the formation of large-scale plankton patches while biotic processes become more important at smaller spatial scales (Pinel-Alloul 1995). Highly productive fine-scale layers are typically found in association with physical and chemical discontinuities (Dekshenieks et al. 2001, Gallager et al. 2004), and may persist for several hours to a few days (McManus et al. 2003). The formation of fine-scale structures may be attributed to several physical processes, such as water 
column stratification, vertical shear, shearing by internal waves, and breakdown of thicker layers into thin layers (Franks 1995, McManus et al. 2005). Biological mechanisms that may influence the development of zooplankton layers include diel vertical migration (DVM), predator avoidance behaviour, locating food patches, and mate search (Folt \& Burns 1999).

Video plankton recorder (VPR) systems enable classification and quantification of plankton, and are useful in resolving distributional structures of plankton at a broad range of spatial scales (Davis et al. 1992, Benfield et al. 1996, Norrbin et al. 1996). The VPR is a noninvasive sampling system, and delicate organisms like gelatinous zooplankton, egg-bearing copepods, and colonial plankton can be surveyed and quantified accurately in their natural orientations without being damaged. Abundance estimates from VPR data of nonfragile zooplankton such as copepods have been shown to be comparable to estimates from net sampling (Benfield et al. 1996). In contrast, fragile plankton such as cnidarians and ctenophores can be underestimated significantly by net samplers compared to optical methods (Remsen et al. 2004). The main goals of the present study were to (1) describe the existence of fine-scale vertical layers of zooplankton populations in nearshore areas using a high resolution sampling scheme, and (2) determine if fine-scale plankton layers were associated with patterns of physical parameters, such as density discontinuities. To resolve the relative spatial distributions and abundances of different zooplankton groups, we used a digital autonomous VPR.

\section{MATERIALS AND METHODS}

The present study was conducted on 19 June 2006 in Nordbotn (Håkøybotn), a semi-enclosed bay $10 \mathrm{~km}$ southwest of Tromsø, northern Norway $\left(69^{\circ} 40^{\prime} \mathrm{N}\right.$, $\left.18^{\circ} 48^{\prime} \mathrm{E}\right)$. Nordbotn is approximately $3 \mathrm{~km}$ long and $2 \mathrm{~km}$ wide, and is connected with the surrounding waters through 2 sounds with sill depths of 4 and $12 \mathrm{~m}$, respectively (Fig. 1). The maximum depth of the bay is $55 \mathrm{~m}$, and the average depth is ca. $30 \mathrm{~m}$. Model simulations have revealed that water exchange in Nordbotn is particularly low compared to the adjacent fjords and sounds, which are more influenced by tidal currents (Audunson \& Næser 1975).

A digital autonomous VPR (Seascan) was used to obtain depth distribution samples of zooplankton in a bay-wide grid $\left(2 \mathrm{~km}^{2}\right)$ consisting of 44 sampling stations distributed between 5 transects (Fig. 1). Sampling started 08:30 $\mathrm{h}$ and finished around 13:00 h. At each station we sampled a vertical profile of the water column by lowering the VPR at an average speed $( \pm \mathrm{SD})$ of $0.41 \pm 0.03 \mathrm{~m} \mathrm{~s}^{-1}$ from the surface and down to $5 \mathrm{~m}$

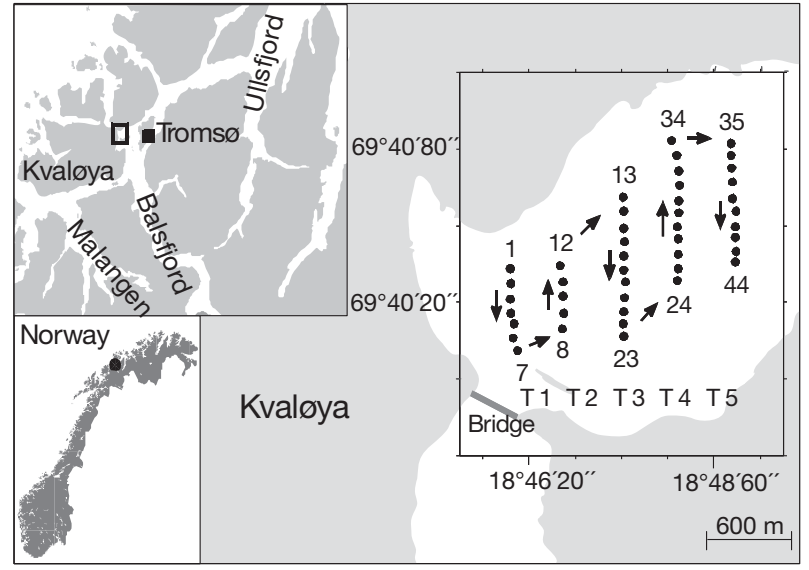

Fig. 1. Nordbotn, Norway, and the surrounding fjords and sounds. Dots mark locations of 44 video plankton recorder (VPR) profile stations along transects T1 to T5. Arrows indicate the sampling path

above the bottom. Only down-casts were used because of the disturbance of the water by wires and tow body during up-tows. The VPR was equipped with a 1.45 megapixel digital camera (Hitachi KP-F120CL black and white), sampling ca. 20 image frames $\mathrm{s}^{-1}$. We used a camera setting with a field of view of $1.25 \times 1.7 \mathrm{~cm}$, a focal depth of $5.49 \mathrm{~cm}$, and a calibrated image volume of $11.6 \mathrm{ml}$. Illumination was provided by a Xenon strobe (10 W, $1 \mathrm{~J}$ per flash) channelled through a $0.2 \mathrm{~m}$ diameter ring illuminator, from which a converging cone of light was generated in front of the camera to achieve a dark field geometry illumination of the targets. The strobe light pulse duration was $3 \mu$ s and was synchronized with the camera shutter. Power was supplied by a $24 \mathrm{~V}$ NiMH battery.

The VPR was supplied with environmental sensors: a Wetlabs ECO Puck fluorometer/turbidity sensor and a Seabird Fastcat CTD sensor (SBE49) operating at $16 \mathrm{~Hz}$. Video image frames were recorded simultaneously with hydrographic and fluorescence data. Images and hydrographic data were recorded by the internal PC104 processor, and the compressed files were stored on a removable hard drive. This hard drive was disconnected from the VPR after deployment, and the data files were downloaded to a computer for decompression and further processing of data.

Plankton images were extracted as regions of interest (ROIs) using the Autodeck image analysis software (Seascan) and saved to the computer disc as TIFF files. Taxonomic identification of plankton was done manually by examining each ROI obtained from down-cast profiles. Vertical movement of the ship may cause variable speed of the VPR through the water column. Duplicate ROIs may appear at speeds below $\sim 0.3 \mathrm{~m} \mathrm{~s}^{-1}$; these were easy to spot and remove manually. Environmental data were obtained using Visual Plankton 
software (Woods Hole Oceanographic Institution, www.whoi.edu/page.do?pid=11348). For each vertical profile, the abundance of different taxa was presented as average water column densities and depth interval concentrations. Identified plankton images were related to environmental data using a timestamp. Postprocessing of data was done using specially developed Matlab routines. The stability of the water column was calculated using the buoyancy frequency $N^{2}=$ $-(g / \rho)(\delta \rho / \delta z)$, where $g=$ gravitational acceleration $\left(9.8 \mathrm{~m} \mathrm{~s}^{-2}\right), \rho=$ density, and $z=$ depth. The buoyancy frequency $\left(\mathrm{rad} \mathrm{s}^{-1}\right)^{2}$ specifies the strength of the density gradient.

\section{RESULTS}

Temperature, salinity, density and buoyancy frequency, and fluorescence data were averaged over all sampling stations along $1 \mathrm{~m}$ depth bins (Fig. 2a-c). Temperature near the surface was ca. $8^{\circ} \mathrm{C}$, decreasing to $4.7^{\circ} \mathrm{C}$ below $25 \mathrm{~m}$. Salinity ranged from $31.5 \mathrm{psu}$ at the surface to 33.5 psu below $20 \mathrm{~m}$. The structure of the water column in Nordbotn was characterized by the existence of a density gradient formed between 15 and $18 \mathrm{~m}$ depth, corresponding to a seasonal temperature and salinity gradient. Across this transition region, the increase in temperature was on average $1^{\circ} \mathrm{C}$, salinity $0.4 \mathrm{psu}$, and density $0.4 \sigma_{\mathrm{t}}$. The buoyancy frequency $\left(N^{2}\right)$ reflected the increase in density around $17 \mathrm{~m}$, which was followed by an average $N^{2}$ of 0.0015 (rad $\left.\mathrm{s}^{-1}\right)^{2}$. The fluorescence maximum occurred between 10 and $15 \mathrm{~m}$ depth, with an average peak around $13 \mathrm{~m}$ coincident with relatively moderate buoyancy frequencies of 0.0001 to $0.0005\left(\mathrm{rad} \mathrm{s}^{-1}\right)^{2}$.

The major zooplankton groups identified were hydromedusae (Rathkea octopunctata and Obelia sp.), copepods (Acartia longiremis, Pseudocalanus acuspes, Microsetella norvegica, and Oithona sp.), ctenophores (Pleurobrachia pileus and Bolinopsis infundibulum), and appendicularians (Fritillaria borealis and Oikopleura sp.). Of the total hydromedusa observations, $R$. octopunctata constituted $87 \%$ and Obelia sp. $13 \%$.

The bathygraphy of Nordbotn varied considerably along the sampling path, and sampling depths fluctuated from 16 to $50 \mathrm{~m}$. The majority of hydromedusae $(79 \%)$ were strongly aggregated from 15 to $20 \mathrm{~m}$ depth, and a distinctive peak occurred at $18 \mathrm{~m}$ depth (Fig. 2d). Copepods were distributed throughout most of the water column and observations peaked at 9, 11, and $21 \mathrm{~m}$ depth (Fig. 2d). Ctenophores showed peaks at $5(20 \%)$ and $7 \mathrm{~m}$ depth (22\%), and appendicularians around $14 \mathrm{~m}$ depth $(23 \%)$. The fraction of the different zooplankton groups sampled below $25 \mathrm{~m}$ was on average $2 \%$ for hydromedusae, $15 \%$ for copepods, $4 \%$ for appendicularians, and none for ctenophores.

Buoyancy frequency in the transition layer (Fig. 3b) peaked at 17 to $18 \mathrm{~m}$ depth at Stns 13 to 15 (Transect 3), 29 to 31 (Transect 4), and 36 to 39 (Transect 5). Peaks of fluorescence (Fig. 3c) were observed at 13.5 (Transect 3), 11 (Transect 4), and $10 \mathrm{~m}$ (Transect 5). The highest fluorescence value was recorded at Transect 5

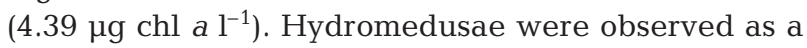
consistent layer between 15 and $20 \mathrm{~m}$ depth along the
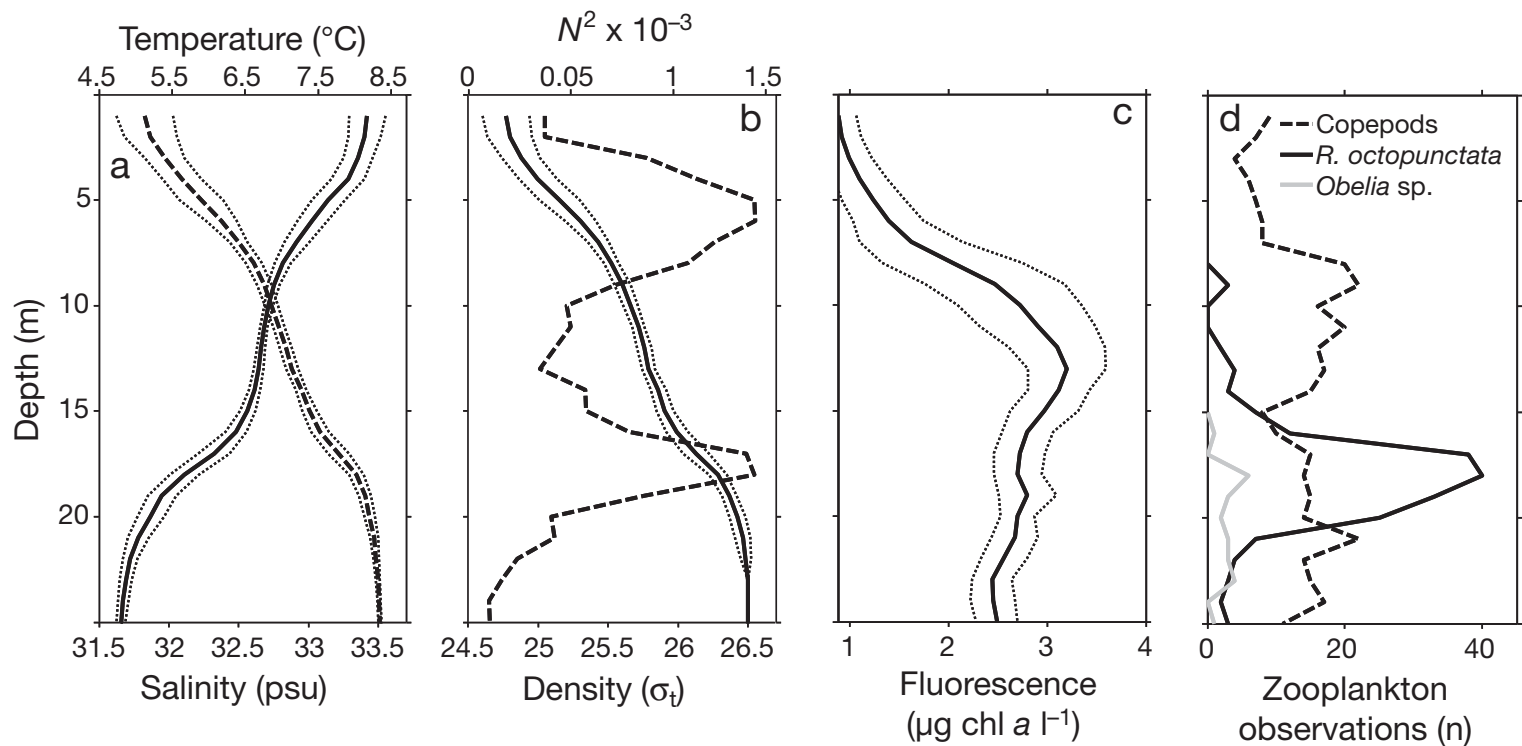

Fig. 2. Environmental data: (a) temperature $\left({ }^{\circ} \mathrm{C},-\right)$ and salinity (psu, - - - -), (b) density $\left(\sigma_{\mathrm{t}},-\right.$ ) and buoyancy frequency

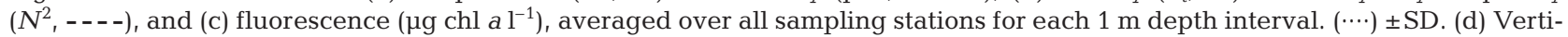
cal distribution of hydromedusae and copepods, presented as total observations of different zooplankton, calculated for each $1 \mathrm{~m}$ depth bin of 18 stations of depths of $\geq 25 \mathrm{~m}$. R. octopunctata: Rathkea octopuncta 

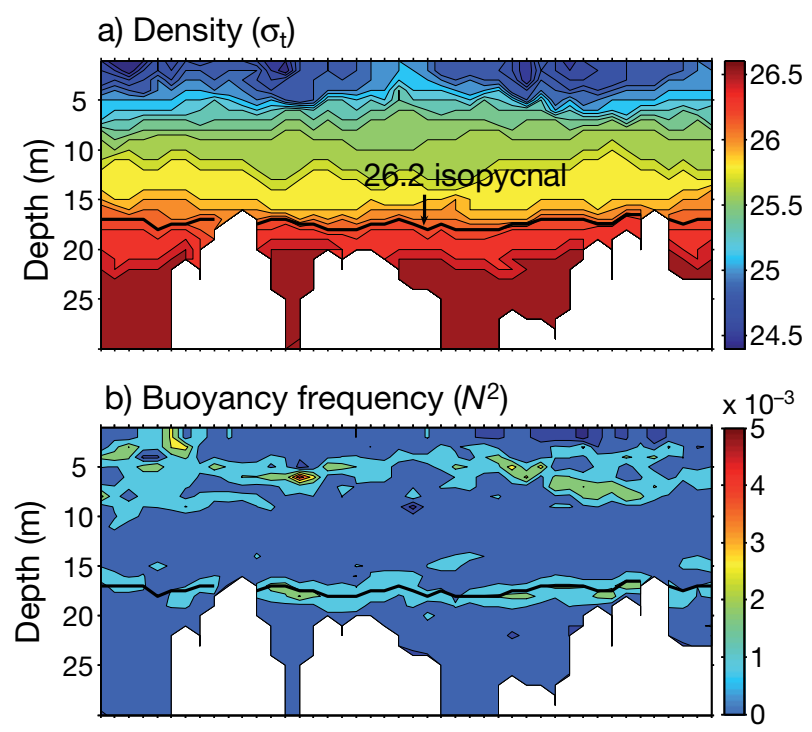

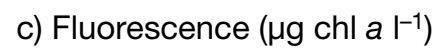

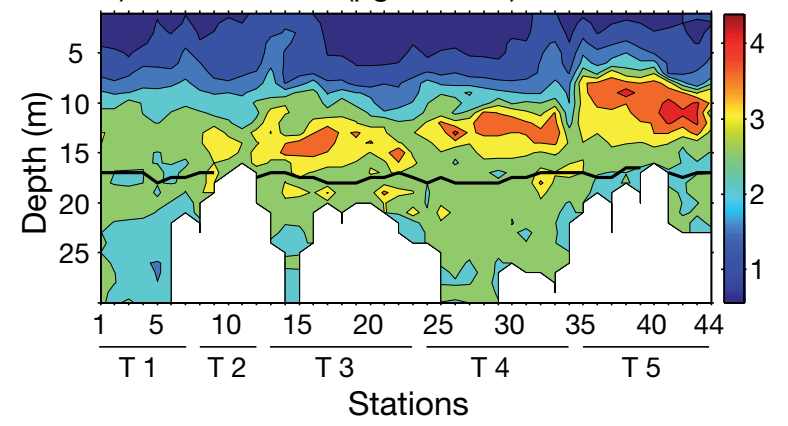

Fig. 3. Contour plots showing depth distribution of (a) density $\left(\sigma_{t}\right)$, (b) buoyancy frequency $\left(N^{2}\right)$, and (c) fluorescence $(\mu \mathrm{g}$ chl $a \mathrm{l}^{-1}$ ) of all video plankton recorder (VPR) profiles, which are presented in sequence from Transects $\mathrm{T} 1$ to T5 according to the sampling path. (-) $26.2 \sigma_{\mathrm{t}}$ isopycnal, illustrating the centre of the density gradient present in the sampling area. The border of the white areas indicates the maximum VPR sampling depth, $5 \mathrm{~m}$ above the bottom

stations (Fig. 4a). The average medusa abundance along this depth interval from Stns 1 to 44 was approximately $2500 \pm 1080$ ind. $\mathrm{m}^{-3}$. Peaks of high hydromedusae abundances (6000 to 10000 ind. $\mathrm{m}^{-3}$ ) were calculated for 11 profiles, and these narrow regions of dramatic abundances were associated with an $N^{2}$ of 0.0006 to $0.0025\left(\mathrm{rad} \mathrm{s}^{-1}\right)^{2}$. Dense aggregations of copepods were found above and below the hydromedusae layer (Fig. 4b), showing concentrations of $>7000$ ind. $\mathrm{m}^{-3}$ at Stn 1 (Transect 1 ) at $19 \mathrm{~m}$ depth, and Stns 30 and 35 (Transect 4 ) at 8 and $21 \mathrm{~m}$ depth, respectively. Average copepod abundance along the depth interval of the hydromedusae layer was $920 \pm 712$ ind. $\mathrm{m}^{-3}$.

The hydromedusae layer corresponded with moderate to high buoyancy frequencies and $95 \%$ of the medusae were located within $N^{2}>0.1 \times 10^{-3}\left(\mathrm{rad} \mathrm{s}^{-1}\right)^{2}$ (Fig. 5). Average water column abundance of hydrom-
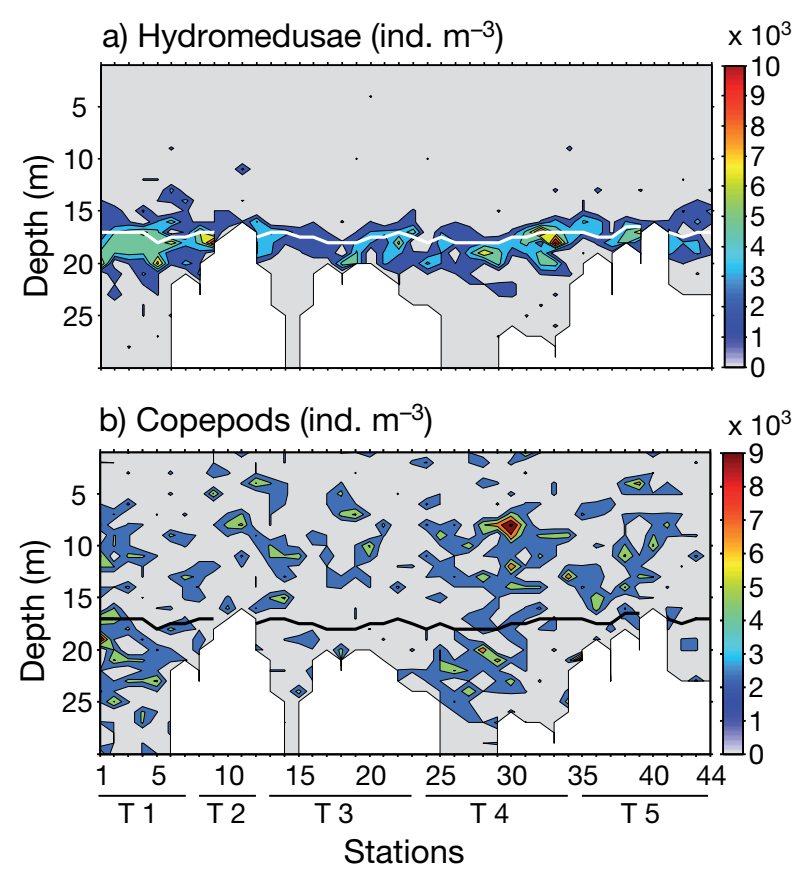

Fig. 4. Contour plots showing the depth distribution and abundance (ind $\mathrm{m}^{-3}$ ) of (a) hydromedusae and (b) copepods of all video plankton recorder (VPR) profiles, which are presented in sequence from Transects T1 to T5 according to the sampling path. White line in (a): $26.2 \sigma_{\mathrm{t}}$ isopycnal, illustrating the centre of the density gradient present in the sampling area. The border of the white areas indicates the maximum VPR sampling depth, $5 \mathrm{~m}$ above the bottom

edusae for all 44 profiles was $581 \pm 234$ ind. $\mathrm{m}^{-3}$ (Rathkea octopunctata $511 \pm 246$ ind. $\mathrm{m}^{-3}$ and Obelia sp. $70 \pm 69$ ind. $\mathrm{m}^{-3}$ ), copepods $944 \pm 368$ ind. $\mathrm{m}^{-3}$, ctenophores $70 \pm 68$ ind. $\mathrm{m}^{-3}$, and appendicularians $40 \pm 40$ ind. $\mathrm{m}^{-3}$. The deepest profiles were found in the innermost transect (Transect 1), which had an average depth of $37 \pm 10 \mathrm{~m}$. Total water column abundance of zooplankton was averaged over this transect: for hydromedusae it measured $26300 \pm 5800$ and for copepods $38480 \pm 15800$ ind. $\mathrm{m}^{-2}$.

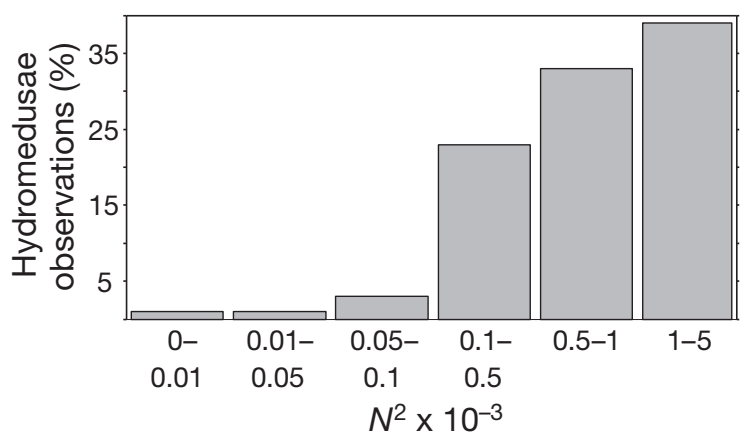

Fig. 5. Hydromedusae observations (\%) located within buoyancy frequency $\left(N^{2}\right)$ intervals from 0 to $5 \times 10^{-3}\left(\mathrm{rad} \mathrm{s}^{-1}\right)^{2}$ 

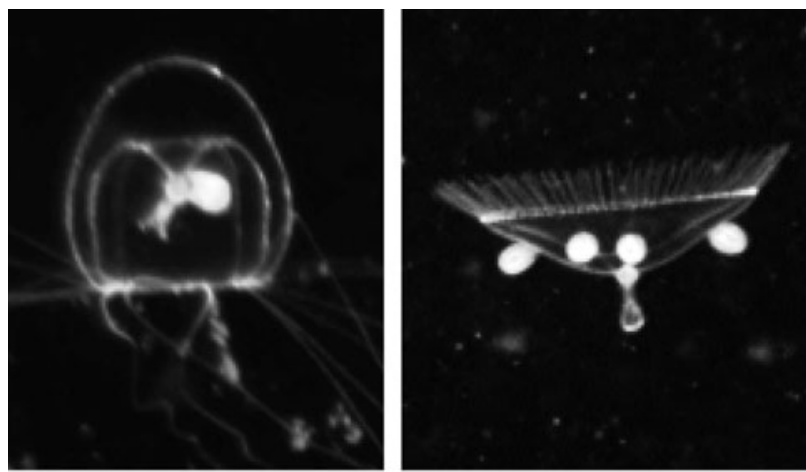

Fig. 6. Rathkea octopunctata and Obelia sp. R. octopunctata with manubrium bud (left) and mature Obelia sp. (right)

The images of different zooplankton categories were distinctive and some individuals could be identified to species level. Images showed Obelia sp. with clearly defined gonads and Rathkea octopunctata with the characteristic bell shape and tentacles. Several individuals of $R$. octopunctata had manubrial buds (Fig. 6).

\section{DISCUSSION}

The present study revealed unusually high abundances of the small hydromedusae Rathkea octopunctata and Obelia sp. throughout the entire sampling area. These occurred in a relatively uniform, fine-scale layer, with peak abundances centered within density interfaces of high buoyancy frequency, indicating regions of density stratification and possibly low mixing rates. Many zooplankton taxa, including gelatinous zooplankton, show a general tendency to aggregate in association with temperature and salinity discontinuities (Arai 1992, Graham et al. 2001), or remain in convergent structures such as Langmuir cells (Hamner \& Schneider 1986). At rest in surface waters, most hydromedusae species are negatively buoyant and sink slowly, and in order to remain at a specific depth they need to attain neutral buoyancy (Mills 1984). Hydromedusae are slow osmoconformers, and when they encounter abrupt salinity differences they may be constrained within these interfaces for hours until osmotic adjustment has occurred (Mills 1984, Mills \& Vogt 1984). Buoyancy regulation in medusae can also be achieved by swimming (Arai 1973, 1976), actively excluding sulphate ions from the mesogloea in order to descend (Mackay 1969), or accumulating lipids in the gastrovascular tract to provide lift (Larson \& Harbison 1989).

In Nordbotn, salinity and temperature discontinuities were linked, which is common in fjords and bays. Because both of these physical characteristics deter- mine the density of the water column, it is difficult to separate their individual effects on hydromedusae aggregation. However, Arai (1976) demonstrated experimentally that ctenophores Pleurobrachia pileus and hydromedusae Sarsia tubulosa aggregated in temperature discontinuity layers, and when these organisms were exposed to coincident transitions of temperature and salinity, the organisms aggregated more strongly. In semi-enclosed basins, the water column above the sill depth is governed by advection, while below the sill depth there is a stable body of water (Farmer \& Freeland 1983). The hydromedusae in Nordbotn may have aggregated below the maximum sill depth in response to currents or turbulence, which could have prevented them from being transported out of the bay by tidally induced currents (selective tidal transport, Forward \& Tankersley 2001). Kopacz (1994) suggested that the medusa of Rathkea octopunctata and other small hydromedusae achieved retention in a tidal channel by ascending to the surface at flood tides and descending to the bottom at ebb tides. In the present study, sampling started $1 \mathrm{~h}$ after high tide and finished close to the following low tide. During that period, no major changes in the depth distribution of the hydromedusae were observed between the profiles. However, due to the relatively short sampling period in the present study, we cannot exclude the existence of tidally induced migration.

Depth distributions of hydromedusae in Nordbotn showed extreme numbers within several vertical profiles. Other investigations using net sampling have demonstrated high water column abundances of Rathkea octopunctata (Blanner 1982, Toyokawa \& Terazaki 1994). Blanner (1982) calculated a maximum abundance of 980 ind. $\mathrm{m}^{-3}$ for this species during spring in Limfjorden, Denmark, while Toyokawa \& Terazaki (1994) found 590 ind. $\mathrm{m}^{-3}$ in Tokyo Bay. Abundance estimates based on VPR data have demonstrated high densities of small hydromedusae (Norrbin et al. 1996, Broughton \& Lough 2006). Broughton \& Lough (2006) described depth distributions of Obelia sp. along the southern flank of Georges Bank, and calculated peaks of abundance of $>12000$ ind. $\mathrm{m}^{-3}$ around temperature and salinity discontinuities. The abundance of Pleurobrachia pileus in the present study (37 ind. $\mathrm{m}^{-3}$ ) is comparable to Wang et al. (1995), who reported an average spring net abundance of 32 ind. $\mathrm{m}^{-3}$ for $P$. pileus from the Seine estuary in France.

How can the extraordinary bloom of Rathkea octopunctata in Nordbotn be explained? The life cycle of this species consists of a pelagic medusa stage and a benthic polyp stage. The medusae multiply asexually by budding off new medusae from the manubrium (Bouillon and Werner 1965, Boero et al. 2002), followed by a period of gamete formation and later sexual 
reproduction (Werner 1958). Manubrial budding may lead to several generations of medusae, and consequently large populations can be produced rapidly (Bouillon et al. 2006). The present study revealed many images of $R$. octopunctata with manubrial buds present, suggesting asexual propagation of medusae. High abundance of hydromedusae often have a seasonal occurrence (Hosia \& Båmstedt 2007). In Nordbotn, medusae blooms of $R$. octopunctata and Obelia sp. take place from late spring to early fall, while these species are absent from the water column outside this period (H. P. Jacobsen \& M. F. Norrbin unpubl. data), possibly existing as benthic hydroids. Numbers of active and dormant benthic hydroid colonies and the amount of reproductive structures producing medusae, combined with favourable environmental conditions, could play a crucial role in the activation of hydromedusae blooms (Boero et al. 2008). The quantity of primary medusae liberated from benthic stages to the water column may therefore be important for the size of medusae blooms. Intense blooms of hydromedusae are usually irregular events (Purcell et al. 2001). This may be due to life cycle adjustments, where hydroid colonies regress to resting stages during seasons of adverse conditions and become active again when favourable conditions return (Gili \& Hughes 1995, Boero et al. 2008).

Aggregation of hydromedusae in or around discontinuities may allow predation on several food organisms often concentrated there. More than $95 \%$ of the hydromedusae observed in the present study had widely extended tentacles, suggesting a typical fishing behaviour that may have been prompted by salinity changes, as demonstrated experimentally in Sarsia tubulosa (Arai 1973, 1976). Rathkea octopunctata is known to feed on several stages of copepods, including genera such as Acartia, Pseudocalanus, and Oithona (Zelickman et al. 1969, Matsakis \& Conover 1991, Pagès et al. 1996). Matsakis \& Conover (1991) showed that high densities of hydromedusae, dominated by $R$. octopunctata, can affect copepod populations considerably and may have the potential to regulate copepod dynamics. The vertical distribution of copepods in Nordbotn revealed peaks above and below the hydromedusae layer, and it is possible that the medusae may have caused extensive reduction of the copepod population size. However, from our data it is not possible to determine if the hydromedusae had been feeding on copepods, or whether copepods were actively avoiding the medusae layer.

Future work in Nordbotn using VPR sampling methods will include investigation of seasonal development and vertical distributions of hydromedusae and other zooplankton. Conclusions regarding the impact of hydromedusae on other zooplankton require stomach analysis of the medusae, and it is important also to find potential hydroid colonies, which may provide a better understanding of the benthic role in the formation of hydromedusae blooms.

Acknowledgements. We thank E. Halsnes, the skipper of RV 'Hyas', and S. Øygarden, who helped with the sampling work. This study was funded by the Norwegian Research Council.

\section{LITERATURE CITED}

Alldredge AL, Cowles TJ, MacIntyre S, Rines JEB and others (2002) Occurrence and mechanisms of formation of a dramatic thin layer of marine snow in a shallow Pacific fjord. Mar Ecol Prog Ser 233:1-12

Arai MN (1973) Behavior of planktonic coelenterates, Sarsia tubulosa, Phialidium gregarium, and Pleurobrachia pileus in salinity discontinuity layers. J Fish Res Board Can 30:1105-1110

Arai MN (1976) Behavior of planktonic coelenterates in temperature and salinity discontinuity layers. In: Mackie GO (ed) Coelenterate ecology and behaviour. Plenum Press, New York, p 211-218

Arai MN (1992) Active and passive factors affecting aggregations of hydromedusae: a review. Sci Mar 56:99-108

Audunson T, Næser H (1975) Investigation of sewage recipients near Tromsø. Vann 4:277-290 (in Norwegian)

> Benfield MC, Davis CS, Wiebe PH, Gallager SM, Lough RG, Copley NJ (1996) Video Plankton Recorder estimates of copepod, pteropod and larvacean distributions from a stratified region of Georges Bank with comparative measurements from a MOCNESS sampler. Deep-Sea Res II 43:1925-1945

Bjørnsen PK, Nielsen TG (1991) Decimeter scale heterogeneity in the plankton during a pycnocline bloom of Gyrodinium aureolum. Mar Ecol Prog Ser 73:263-267

Blanner P (1982) Composition and seasonal variation of the zooplankton in the Limfjord (Denmark) during 1973-1974. Ophelia 21:1-40

Boero F, Bouillon J, Piraino S, Schmid V (2002) Asexual reproduction in the Hydrozoa (Cnidaria). In: Hughes RN (ed) Reproductive biology of invertebrates, Vol 11, Progress in asexual reproduction. Oxford and IBH Publishing, New Delhi, p 141-158

Boero F, Bouillon J, Gravili C, Miglietta MP, Parsons T, Piraino S (2008) Gelatinous plankton: irregularities rule the world (sometimes). Mar Ecol Prog Ser 356:299-310

Bouillon J, Werner B (1965) Production of medusae buds by polyps of Rathkea octopunctata (M. Sars) (Hydroida Athecata). Helgol Mar Res 12:137-148

Bouillon J, Gravili C, Pagés F, Gili JM, Boero F (2006) An introduction to Hydrozoa. Mem Mus Natl Hist Nat 194

> Broughton EA, Lough RG (2006) A direct comparison of MOCNESS and video plankton recorder zooplankton abundance estimates: possible applications for augmenting net sampling with video systems. Deep-Sea Res II 53:2789-2807

Cowles TJ, Desiderio RA, Carr ME (1998) Small-scale planktonic structure: persistence and trophic consequences. Oceanography 11:4-9

Davis CS, Gallager SM, Solow AR (1992) Microaggregations of oceanic plankton observed by towed video microscopy. Science 257:230-232

> Dekshenieks MM, Donaghay PL, Sullivan JM, Rines JEB, 
Osborn TR, Twardowski MS (2001) Temporal and spatial occurrence of thin phytoplankton layers in relation to physical processes. Mar Ecol Prog Ser 223:61-71

Donaghay PL, Rines JEB, Sieburth JM (1992) Simultaneous sampling of fine scale biological, chemical and physical structure in stratified waters. Arch Hydrobiol 36:97-108

Farmer DM, Freeland HJ (1983) The physical oceanography of fjords. Prog Oceanogr 12:147-219

Folt CL, Burns CW (1999) Biological drivers of zooplankton patchiness. Trends Ecol Evol 14:300-305

Forward RB, Tankersley RA (2001) Selective tidal-stream transport of marine animals. Oceanogr Mar Biol Annu Rev 39:305-353

Franks PJS (1995) Thin-layers of phytoplankton: a model of formation by near-inertial wave shear. Deep-Sea Res I 42:75-91

Gallager SM, Yamazaki H, Davis CS (2004) Contribution of fine-scale vertical structure and swimming behavior to formation of plankton layers on Georges Bank. Mar Ecol Prog Ser 267:27-43

> Gentien P, Lunven M, Lehaitre M, Duvent JL (1995) In-situ depth profiling of particle sizes. Deep-Sea Res I 42: $1297-1312$

Gili JM, Hughes RG (1995) The ecology of marine benthic hydroids. Oceanogr Mar Biol Annu Rev 33:351-426

Graham WM, Pages F, Hamner WM (2001) A physical context for gelatinous zooplankton aggregations: a review. Hydrobiologia 451:199-212

Hamner WM, Schneider D (1986) Regularly spaced rows of medusae in the Bering Sea: role of Langmuir circulation. Limnol Oceanogr 31:171-177

Hanson AK, Donaghay PL (1998) Micro- to fine-scale chemical gradients and layers. Oceanography 11:10-17

Holliday DV, Pieper RE, Greenlaw CF, Dawson JK (1998) Acoustical sensing of small-scale vertical structures in zooplankton assemblages. Oceanography 11:18-24

- Hosia A, Båmstedt U (2007) Seasonal changes in the gelatinous zooplankton community and hydromedusa abundances in Korsfjord and Fanafjord, western Norway. Mar Ecol Prog Ser 351:113-127

Johnson PW, Donaghay PL, Small EB, Sieburth JM (1995) Ultrastructure and ecology of Perispira ovum (Ciliophora, Litostomatea): an aerobic, planktonic ciliate that sequesters the chloroplasts, mitochondria, and paramylon of Euglena proxima in a micro-oxic habitat. J Eukaryot Microbiol 42:323-335

Kopacz U (1994) Evidence for tidally-induced vertical migration of some gelatinous zooplankton in the Wadden Sea area near Sylt. Helgol Mar Res 48:333-342

Larson RJ, Harbison GR (1989) Source and fate of lipids in polar gelatinous zooplankton. Arctic 42:339-346

Mackas DL, Denman KL, Abbott MR (1985) Plankton patchiness: biology in the physical vernacular. Bull Mar Sci $37: 652-674$

Editorial responsibility: Hans Heinrich Janssen, Oldendorf/Luhe, Germany
Mackay WC (1969) Sulphate regulation in jellyfish. Comp Biochem Physiol 30:481-488

Matsakis S, Conover RJ (1991) Abundance and feeding of medusae and their potential impact as predators on other zooplankton in Bedford Basin (Nova Scotia, Canada) during spring. Can J Fish Aquat Sci 48:1419-1430

> McManus MA, Alldredge AL, Barnard AH, Boss E and others (2003) Characteristics, distribution and persistence of thin layers over a 48 hour period. Mar Ecol Prog Ser 261:1-19

- McManus MA, Cheriton OM, Drake PJ, Holliday DV, Storlazzi CD, Donaghay PL, Greenlaw CF (2005) Effects of physical processes on structure and transport of thin zooplankton layers in the coastal ocean. Mar Ecol Prog Ser 301:199-215

Mills CE (1984) Density is altered in hydromedusae and ctenophores in response to changes in salinity. Biol Bull 166:206-215

Mills CE, Vogt RG (1984) Evidence that ion regulation in hydromedusae and ctenophores does not facilitate vertical migration. Biol Bull 166:216-227

Norrbin MF, Davis CS, Gallager SM (1996) Differences in fine-scale structure and composition of zooplankton between mixed and stratified regions of Georges Bank. Deep-Sea Res II 43:1905-1924

> Pagès F, González HE, González SR (1996) Diet of the gelatinous zooplankton in Hardangerfjord (Norway) and potential predatory impact by Aglantha digitale (Trachymedusae). Mar Ecol Prog Ser 139:69-77

> Pinel-Alloul B (1995) Spatial heterogeneity as a multiscale characteristic of zooplankton community. Hydrobiologia 300-301:17-42

Purcell JE, Graham WM, Dumont HJ (eds) (2001) Jellyfish blooms: ecological and societal importance. Developments in hydrobiology, No. 155. Kluwer Academic, Dordrecht

> Remsen A, Hopkins TL, Samson S (2004) What you see is not what you catch: a comparison of concurrently collected net, Optical Plankton Counter, and Shadowed Image Particle Profiling Evaluation Recorder data from the northeast Gulf of Mexico. Deep-Sea Res I 51:129-151

Toyokawa M, Terazaki M (1994) Seasonal variation of medusae and ctenophores in the innermost part of Tokyo Bay. Bull Plankton Soc Japan 41:71-75

Wang Z, Thiebaut E, Dauvin JC (1995) Spring abundance and distribution of the ctenophore Pleurobrachia pileus in the Seine estuary: advective transport and diel vertical migration. Mar Biol 124:313-324

> Werner B (1958) Die Verbreitung und das jahreszeitliche Auftreten der Anthomeduse Rathkea octopunctata M. Sars sowie die Temperaturabhängigkeit ihrer Entwicklung und Fortpflanzung. Helgol Wiss Meeresunters 6:137-170

> Zelickman EA, Gelfand VI, Shifrin MA (1969) Growth, reproduction and nutrition of some Barents Sea hydromedusae in natural aggregations. Mar Biol 4:167-173

Submitted: October 10, 2008; Accepted: February 2, 2009 Proofs received from author(s): March 30, 2009 